\title{
The Construction of Political Ecology on the horizon of Ruling of law
}

\author{
ZHOU Ping ${ }^{1, a *}$, JIANG Wei, ${ }^{2, b}$
}

School of Management, China West Normal University, Nannchong, P.R. China,637000

azhoujinyu2718@163.com, ${ }^{b} 592156443 @ q q . c o m$

Keywords: Rule of law; Political ecology; Focused point; Construction

\begin{abstract}
The political ecology is a comprehensive reflection of party's work style, government's conduct and social trust, the construction of which has a significant effet on improving Party and government conduct, enhancing public credibility and politic trust.It is particularly urgent and important to build a fresh and clean political eco-environment under the current requests of pushing forward the rule of law in an all-round way. For this,we must focus on the key points to build a good political ecological, we must take the rule of law as the cornerstone,take political culture as the soul and strict party discipline.What's more, it is of great concern to shape a noble political personality, build a law-based and service-oriented government, enhance the execution system, strengthen the power supervision of power and pure the leading cadres.Finally it's believed that the rights of people can be safeguarded and a good political environment can be built.
\end{abstract}

\section{Instruction}

In an important speech of the Sixteenth collective learning at Politburo conference on June 30, 2014, Xi Jinping ${ }^{(1)}$ stressed"strengthening Party building, we must create a favorable political environment to strengthen our Party building, namely,to have a good political ecology "; January 13, 2015, at the Fifth Plenary Session of the eighth session of the Central Commission for Discipline Inspection, Xi Jinping sharply pointed out again: "Anti-corruption situation remains severe and complicated,mainly because we has not yet achieved a landslide victory in the process of anti-corruption,corrupt activity decreased but not extinct, the anti-corruption institutional mechanisms established but still not perfect, ideological education strengthened but not build a strong ideological line of defense, reducing the stock of corruption,curb corruption increment, reconstruction of the political ecology reminds to be arduous"; during the two sessions this year, $\mathrm{Xi}$ Jinping in Jiangxi delegation's deliberations, Xi Jinping stressed again:" the natural environment should be beautiful, the political environment should also be beautiful. "[1] Thus, in the situation of four total strategic layouts, under the requirements of advancing the rule of law roundly, it is particularly important and urgent to build a bright, clean, clear and green political ecology.

\section{logical relations between the rule of law and the construction of political ecology}

The 4th plenary session of 18th CPC Central Committee raise the rule of law to a new height.In the times of reform and anti-corruption, only on the basis of the authority of the rule of law,can we build a beautiful political environment.Dramatic reform means the increasing of resistance, the progress and friction coexist, both opportunities and challenges.To reform,we must create a clear political atmosphere and eliminate all disadvantage factors, let a bright blow into the gate of reform, finally build a good platform for the political ecology for the socialist

(1) Xi Jinping:President of the People's Republic of China. 
modernization.

\section{Building a favourable political ecology is the inner requirement of the rule of law}

As the name implies, political ecology means the political environment.From the macro level, purification of the political ecological is directly related to the process of construction of the rule of law in our country.The spirit of law can frighten the wrongdoings, and then form a good political order.If political ecological is clear,the resistance of administration will reduce, the reform can be hold fluently; On the contrary, if political ecological is like dirty water and cigar smoke, the road of ruling by law can't be plain. From the micro level, the political ecology is related to the construction of party's ability, a clean party relates to political civilization and spiritual civilization construction in our country, therefore, only to shape a awe-inspiring ruling environment, can we greatly improve the party's ruling construction and the party's style construction, then to promote the overall goal of governing the country according to law.

\section{Building a favourable political ecology is an important goal of the rule of law}

With the continuously improvement of material level today, people's spiritual world has suffered from great impact, multifarious material world and enhancement of the spirit of the world are irreconcilable contradictions, it becomes a striking contrast between the citizen's increasingly strong consciousness and constantly corruption and wonders exposed.Those cases that party cadres violate the law and discipline or violate the eight provisions hurt interests of the masses of the people, those behavior has become an important trigger to cause conflicts and confrontations. Only put power's rent-seeking and corruption into the system of framework, these phenomena will be curbed.Thus, one of the important objectives of rule of law is to realize a clear political ecology and to safeguard the fundamental interests of masses of the people. It is said that the modernization of the management system and management ability at the third plenary session of the 18 , modernization of governance is a tool, the method is to improve and advance, the forces is to put into effect,to reach the total goal of reforming further,in addition to a series of reform measures, we still need to inject fresh blood into the reform from the external environment.

\section{Building a favourable political ecology and the rule of law are mutually reinforcing}

A Good political ecology is related to the style of the cultivation of clean government of our country, the ascension of the government's ruling ability, the government's credibility and its image construction,the realization of the interests of the masses and socialist democratic development.The aim of ruling by law is to ensure that the socialist construction can be followed by rule,realize socialist democracy.They both in essence complement each other, promote each other.At the present time,in our country,citizen's material needs is no longer the only pursuit,spiritual needs become polycentric and diversification, this is a manifestation of the promotion of spiritual civilization,the citizens pay attention to the realization of their own interests more and more, which needs an enough open and transparent political environment to ensure the realization of their interests. At the same time, when the reform is running deeply, there are some people bolted into the gap of the system, in order to protect the vested interests or achieve their own interests, they damage the interests of others, it is blasphemy to the system and its own image,the occurrence of these phenomena seriously hindered our country's socialist democratic process, therefore,correcting these wrongdoings through rule and law will be create a pretty political ecology through rule and law.

\section{The focus of building a comfortable political ecology from the prespective of the rule of law}

The political ecology is a comprehensive reflection of party's work style, government's conducts and social value.If political ecology was good, the people's heart will be right and healthy atmosphere will be there; If politics was not good, people's heart will be divided and all kinds of 
disease will breed ${ }^{[2]}$.Currently,under the requirement of the rule of law,we must focus on the key points to construct a clean political environment.

\section{The key to a good political ecology is the construction of a clean and honest party}

Our party's standpoints and mission means that party's political ecological is health or not, which not only have great influence on all party members and cadres, but also on other social organizations and even the entire national political system ${ }^{[3]}$. The leadership of the party is the direction of stepping into a well-off society,so we should adhere to the party's direction and the direction of serving the people.For the party's construction,the most important thing is the party conduct.One is the ideological style construction,party members and cadres should play an exemplary role, practice the CPC Central Committee's eight-point decision and the education of the mass line.The second is the work style construction of system.If power is beyond the cage of system, which will make the system produce corruption,therefore, the system construction becomes an important restriction factor between the balance of rational behaviours and freedom behaviours. The third is work style construction in practice.Party members and cadres should keep their responsibility and mission in mind, take the mass line into action.

a good political ecological building is based on the construction of government conduct, enforcing the law strictly

"Political Ecology is a social and political ecology in terms of the natural ecology, environment and ecological order, is a comprehensive reflection of the relationship of political structure, political struction and the various political elements, it reflects a situation of the political life and political development environment, it is a comprehensive reflection of a place of work style, political winds and social atmosphere,"and political environment is the effective protection of government social governance, essentially a"soft environment"or"soft power ${ }^{[4]}$."The principal-agent theory advocates, to realize their own interests and aspirations,citizens will delegate the government as an agent, the government have the power and responsibility to achieve the aspirations of the clients. The public service is related to the people's interests, the most basic functions of government is to provide public services.If the government's administration win citizens' trust,people will maintain a good order self-consciously.Therefore, a service-oriented and transparent government is imperative.

\section{The foundation of good political ecological building is law construction, to strengthen the system construction}

With the development of human spiritual civilization,the rights of people should be safeguarded in line with law.If you want a more fair power,a law-based administration is essenial.if the reform want to go further, the existing interests pattern will be demaged, power's rent-seeking become wrong doings which will be done by those oppotunitist.,so it is imperative to ruling by law strictly.Only by rulimg by law,the power can be carryed out fairly. On the external level ,system shows a series of rules, written specifications and visible civilization, On the inner level,it is a kind of ethical and moral norms.Political ecology building needs solid construction of the rule of law as the backing and the increasingly perfect system security as the foundation, precludes "the four winds", all these need the constraints of the legal system, the more perfect the rule of law is, the more clear political ecolgy is.

\section{The soul of a good political ecology is political cultrue,to create socialist core values}

To create a good politicalecology,we must focus on the pure political culture including inside and outside the party.First is to become a fine political system,the system is a solid factor to make up the political culture,it benefits to regulate all kinds of political behaviorto stress the effects of the system;the second is to have a series of political rules,it is disgraceful without proper behavior.only 
abiding by these behavior,can political culture be pure. Thirdly, the party member cadre must have the standards of political behavior, prevent some wrongdoings; fourthly, the society should form a noble political spirits, party members and cadres should practice the socialist core values consciously.In the new period of strengthening the reform, it is beneficial to strengthen social cohesion and centripetal force to carry forward the good political culture, only the soul is pure, political ecological environment can be clear.'Political culture is the soul of political ecology, the thought and behavior of a political subject will be affected by the political culture, the vitality of a political party begins with the vitality of the culture of the inside party, the sinking of a political party begins with the sinking of the culture of the inside party ${ }^{[5]}$."

\section{The path of constructing the political ecology from the prespective of the rule of law}

At present, with strong appealing of ruling by law roundly, we must build a good political ecological environment to create a beautiful scenery of the environment for the four comprehensive strategic plan, and reduce the resistance of reform, in order to pass the rough period smoothly.

Promoting the construction of the clean party, stricting party discipline and strengthing party's work style construction

The party's thought is the navigator of the socialist construction, only a pure party and pure government's cadres can make a clean and fresh political ecosystem. To achieve the overall goal of socialist construction, building a well-off society cannot leave the party's guidance, the construction of the Party and an honest and clean government is the most fundamental construction, we must pratice the mass line from the depths of the soul, to serve for the people on the right path, it needs to be focus on the construction of the party's ideological style and organization.

Clearing political stance, studying the party's guiding ideology and concept further, stricting party discipline

Thoughts of freeing up the mind, seeking truth from facts and serving the people are the soul of the party, which represents the core values of the party, only by setting up the correct values, can our party play the role of central leadership. This requires that we must study the party's guiding ideology, especially party members and cadres should have high political consciousness, grasp the party's core idea accurately, set up the correct values and views, strict party discipline and norms, strengthen the construction of core cohesion.

Puring party members and cadres and punishing the behaviours of violenting party's discipline

The provisions,such as such as "eight rules", "four winds","Three solid",will force party members and cadres to perform politely and regularly. Meanwhile,those provisions reflects the willing of ruling the praty ${ }^{[6]}$. on the one hand,to pure the political ecology,we must reduce the number of party members, improve the quality of party members, select the good, eliminate the bad, only to store the members of good quality,we can drive the whole party organization construction, thus promoting the party's work. On the other hand, we must intensify the strength of punishment for party members and cadres who violented the rule, continue to intensify anti-corruption, adhere to the anti-corruption's determination, only to pure party member cadres, we can improve and optimize the entire party .

\section{Promoting the law-based governance of the country and enhancing public credibility}

Government's construction is related to people's interests and their welfare, the improvement of government governance ability will set up an fair and orderly eco-environment in the whole society. The details are as follows:

Enhancing the government's administrative capacity, dealing with the relationship between government and market well 
A clear politics is particularly important at the period of deepening the reform, which is related to the progress of the comprehensive reform, thus, the government needs to have a self-revolution.At the period of planned economy, the government did not play the role of serving functions, which precludes the market holders to display their initiative. The 18th Party Congress said that to deal with the relationship between government and market is to meet the needs of the market's operation. Letting the market play a decisive role means that the government must reduce the decentralization, correctly handle the relationship between centralization and decentralization, to enliven the market economy is to let the market main holders attend the market competition; At the same time, the government must increase the supervision of power and decentralization, widen the way of supervision.

Strengthening the construction of a service-oriented government, perfecting the mechanism of citizen participation

As a consignor of the interests of the people, the most basic function of the government is to provide public service and to be a provider.Today people's interests and needs are diversified, the government should listen their voice to guarantee the democracy of government decision-making.On the one hand, perfecting the mechanism of citizen participation in decision-making system, establishing the organization of expressing public opinion; On the other hand,To broaden the channels of citizens participating in decision making, which can provide a good expression environment for citizens.

Establishing a sound legal system, pushing forwarding the rule of law in an all-round way

Countinuing to put people first,setting up the consciousness of the rule of law

The rule of law are the reliable guarantee of the reform, in order to bulid a solid barrier,we should insist the idea of ruling by law. Therefor, the whole party must set up the consciousness of the rule of law, the whole society must keep a clear concept, let the power be shutted into the cage of system, with the rule of law as the goal, let the concept of ruling by law deeply root in people's hearts, build a solid framework fundamentally for the political ecology.

Improving the legislative process and judicial supervision, promoting the execution of system

At present,there are many problems during the process of administration,such as imperfect legal system for poor executivers' quality.Therefore, the first thing is to establish perfect legislation system,define the scope of legislation and law enforcement;Second,to ensure the system's stability and continuity,make system become a solid wall to regulate people's behavior;Once again,to strengthen the judicial supervision,ensure legislative fairness and justice,make the interests of the people have a solid backing; Finally,to improve the executivers' quality,optimize the structure of their quality,make them truly become a servant of the people.

\section{Stricting the selection and employment mechanism,shaping a pretty personnality, implementing the supervision and accountability mechanisms}

Optimizing the structure of leadership and the quality of civil servants,arising the standards of hiring people,buliding a pretty personnality

The political ecology's most important content is people, We should improve the credibility and insist the pcinciples of democracy,open,competitive and selecting the good,to form a vibrant mechanism, promote the excellent talents to stand out,which is the key to develop cadres with high quality $^{[7]}$. If leading cadres abuse the right,which will ruin the whole political ecology, "people will fall into bad from the beginer",If you set a good example, everything will be OK.So, we should build a clear atmosphere from loyal officials ${ }^{[8]}$.To build a positive political ecological, the political 
personality is the most important factor.First,we should optimize the structure of the party members,especially as a leader, loyal behaviors can make it.Second,the party's cadres must be loyal to the party and the people, implement the party's guidelines and policies.Only to be strict with the gateway of hiring people,discipline, prevent and control wrongdoings from beginning, can cadres promote a good political ecological.

Insisting on anti-corruption and refusing overthrow, increasing the intensity of power supervision, implementing the long-term accountability system

To insist on anti-corruption is to insist severe woke systle. We should put the corruption in the first place, punish corruption, speed up a long-term mechanism of anti-corruption, and correct "spelling dad and power","going the back door", resolutely,etc. Increase the power's supervision, perfect the system's arrangement, let the power run in the sun.In addition, the implementation of cadre's accountability mechanism is important, and to create a transparent ecological environment for civil servants's administrative activities.

\section{Conclusion}

Under the guidance of the rule of law,it is urgent to bulid a clean and confortable political eco-environment. "If political ecosystem is polluted, political environment will be bad and produce corruption; If political ecological is clean and healthy, political environment will be fine and it will let people's mind and force together and inspire troop morale.So, the conditions of political ecology determines the political environment and influences party's image ."There are three basic points from above:(1)The construction of political ecology should be relationed with the rule of law,they both complement each other.(2)We should find the key points of political ecology,there are Party and government conduct,party discipline,the law-based governance and political culture.(3)To bulid the political ecology,we should put people first and take fulfilling people's intrests as final goal,for our government is an innovative and service-oriented organazition.Therefore,we must be build a fresh and positive political eco-environment comprehensively.

\section{References:}

[1,3] Bao Xinjian.Optimize the Political Ecology in Party[EB/OL].

http://news.gmw.cn/2015-05/13/content_15645696.htm,2015-05-13(in Chinese).

[2]Liu Yunshan.Build a Good Political Ecology Industriously[EB/OL]. http://theory.people.com.cn/n/2015/0518/c40531-27015254.html,2015-05-18(in Chinese).

[4]Cao Shuai,Xu kaiyi.Mediate Social and Political Mood and Ascend the Government's Management ability. Management Science.2015(3):8(in Chinese).

[5]Wang Yuhua.Find the Focus of Optimizing the Political Ecology.Policy,2014(12):80(in Chinese). [6]Liu Linli,Wu Jianglong.The thinking of A long-term Mechanism for the Party's Style Construction. The CPC shanxi made organ journal of Party School, 2015 (2):78(in Chinese).

[7] Several Major Issues about Strengthening and Improving Party Building at the Central Committee of the Communist Party of China under the New Situation Decision. Qiushi Journal, 2009 (19):10(in Chinese).

[8]Shen Haixiong.Seize the key to Realize a Clear and Fresh Political Ecology[EB/OL]. http://theory.people.com.cn/n/2015/0518/c40531-27015304.html,2015-05-18(in Chinese). 